\title{
DICTYOCONELLA HENSON, 1948, UPPER CRETACEOUS LARGER BENTHIC FORAMINIFERA: A TAXONOMIC REVISION WITH THE ESTABLISHMENT OF GUSICELLA GEN. NOV. (TYPE-SPECIES DICTYOCONELLA MINIMA HENSON)
}

\author{
Felix Schlagintweit ${ }^{1}$ \& ${\text { Koorosh } \text { Rashidi }^{*}}^{*}$
}

Received: 19 January 2021/ Accepted: 10 February 2021 / Published online: 17 February 2021

\begin{abstract}
In his monograph on Mesozoic-Cenozoic Larger Benthic Foraminifera from the area of Middle East and south-western Asia, Henson (1948) erected the genus Dictyconella for more or less "compressed-conical" dictyoconids including $D$. complanata (type-species) and D. minima. Both are however, structurally completely different, e.g. aligned (in the latter) versus alternating structural elements (in the former), and cannot either belong to the same genus or the same subfamily (Dictyoconinae versus Dictyorbitolininae). Therefore, the new genus Gusicella is erected with the type-species Dictyoconella minima, resulting in the new combination Gusicella minima. Gusicella represents the only taxon of the Dictyorbitolininae in the Upper Cretaceous Global Community Maturation Cycle of Larger Benthic Foraminifera (here: conical agglutinated). Due to the revision, Dictyoconella is described as a monospecific genus and an assumed Maastrichtian newcomer which, like Gusicella, became extinct shortly afterwards, namely at the K-Pg boundary mass-extinction event. Both taxa appear to be restricted to the former Arabian Plate of the southern Neotethyan margin. The new data provided are based on material from the Maastrichtian Tarbur Formation of southwestern Iran (Zagros Zone).
\end{abstract}

Keywords: Late Cretaceous, Larger Benthic Foraminifera, Orbitolinidae, systematics, biostratigraphy

\section{INTRODUCTION}

In his important monograph on Mesozoic-Cenozoic Larger Benthic Foraminifera from the area of the Middle East and south-western Asia, Henson (1948) described 14 new genera, and 27 new species among many agglutinated taxa from the Upper Cretaceous (Fig. 1, Tab. 1).

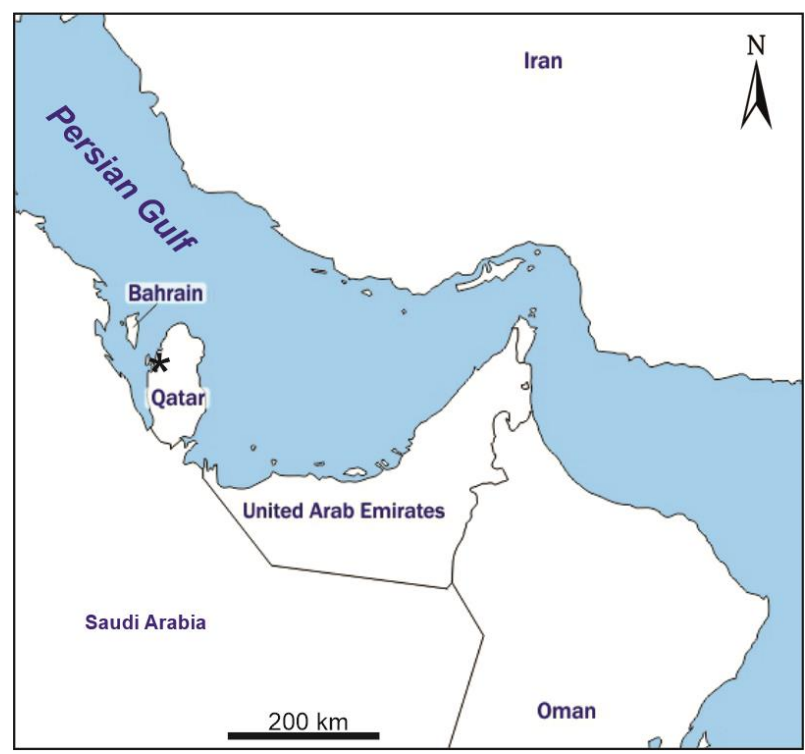

Fig. 1 Map of the Persian Gulf area showing the location of Dukhan Well in Qatar, the type-locality of Dictyoconella complanata Henson and Gusicella minima (Henson) gen. et comb. nov. (from free maps, https://d-maps.com).
Table 1 Agglutinated taxa described by Henson (1948) from the Upper Cretaceous of Qatar (Dukhan Well).

\begin{tabular}{|c|c|}
\hline $\begin{array}{l}\text { Cenomanian } \\
\text { Mishrif Formation }\end{array}$ & $\begin{array}{l}\text { Maastrichtian } \\
\text { Simsima Formation }\end{array}$ \\
\hline $\begin{array}{l}\text { Dictyoconella minima n. sp. } \\
\text { Orbitolinella depressa n. } \\
\text { gen., n. sp. } \\
\text { Qataria dukhani n. gen., n. } \\
\text { sp. } \\
\text { Dohaia planata n. gen., n. } \\
\text { sp. }\end{array}$ & $\begin{array}{l}\text { Broeckinella arabica n. } \\
\text { gen., n. sp. } \\
\text { ? Dictyoconella minima n. } \\
\text { sp. } \\
\text { Dictyoconella complanata } \\
\text { n. gen., n. sp. } \\
\text { Lituonelloides compressus } \\
\text { n. gen., n. sp } \\
\text { Loftusia coxi } \mathrm{n} . \mathrm{sp} \text {. }\end{array}$ \\
\hline
\end{tabular}

Some of them, such as the Lower Cretaceous Dictyoconus arabicus, have meanwhile been taxonomically revised (e.g. Cherchi \& Schroeder, 1991). Others have been inadequately illustrated and are still poorly known today. Among them is the genus Dictyoconella, one of the "Key Mesozoic Benthic Foraminifera of the Middle East" (Whittaker et al., 1998) established with two species: the type-species D. complanata from the Maastrichtian of Qatar (= Simsima Formation), and D. minima from strata with an age of "most probably Upper Cenomanian or Turonian" of Qatar ... and "a single specimen, possibly of this species ... in Maastrichtian limestones" of Iraq (op. cit., p. 26). The two species assigned to the family

\footnotetext{
${ }^{1}$ Lerchenauerstr. 167, 80935 Munich, Germany, felix.schlagintweit@gmx.de 

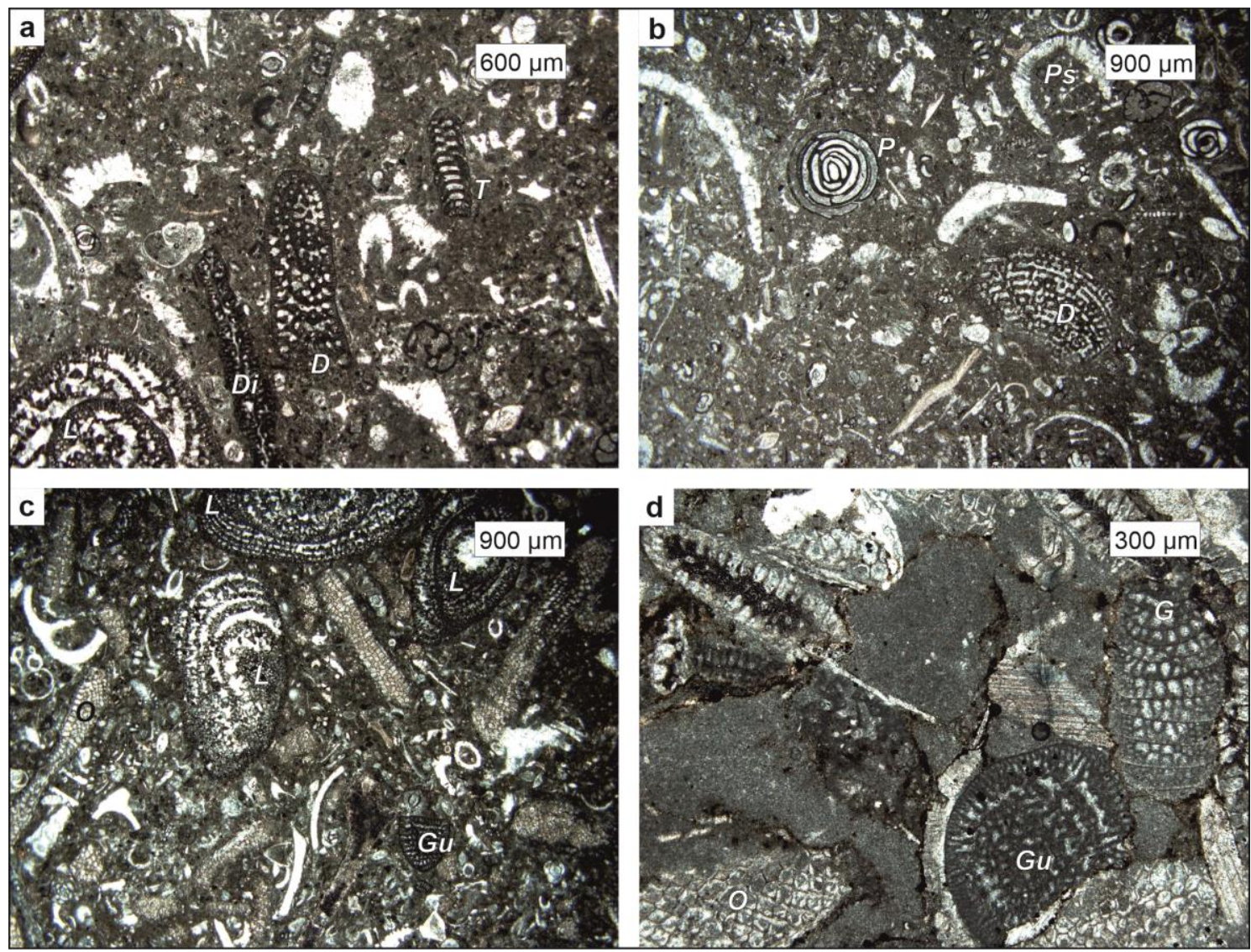

Fig. 2 Microfacies with Dictyoconella complanata Henson (a-b) and Gusicella minima (Henson) gen. et comb. nov. (cd) from the Maastrichtian Tarbur Formation of the Naghan (a-b) and Mandegan sections (c-d), SW Iran (Zagros zone). Abbreviations: $D=$ Dictyoconella, $D i=$ Dicyclina, $G=$ Gyroconulina, $G u=$ Gusicella, $L=$ Loftusia, $O=$ Omphalocyclus, $P=$ Pseudonummoloculina, $P s=$ Pseudocymopolia, $T=$ Tarburina . Thin sections: $2 \mathrm{Ng} 81$ (a), 2Ng 81-4 (b), Rt 109 (c), Rt 105 (d).

Orbitolinidae were poorly illustrated. According to Henson, both possess a subepidermal polygonal pattern, and D. minima main partitions (= primary beams) that are lacking in $D$. complanata. The test of $D$. complanata is distinctly compressed with subparallel opposite sides, flabelliform (like in cuneolinids) whereas the one of $D$. minima only slightly and may show ellipsoidal transverse sections (Henson, 1948, pl. 11, figs. 8, 10). In addition, Henson supplied morphological details in the description of D. minima that are not discernible in the provided illustrations, such as the occurrence of a planispiral initial coil. It is worth mentioning that in the monograph of Henson the holotype has been illustrated only for $D$. complanata (Henson, ibid., pl. 6, fig. 2 and refigured herein in Figure $3 a)$. For D. minima however only paratypes were illustrated. Douglass (1960, p. 256) stated that "it is likely that the form described by Henson (1948) as Dictyoconella is merely a variant of the genus Iraqia Henson" a form where "the partitions are reticulate throughout the central area". Although almost 80 years have passed since their description, their systematic position and biostratigraphy reqire substantial improvements. Structural differences with generic and suprageneric importance between the two taxa were observed by Schlagintweit et al. (2016). Based on new data from the Maastrichtian Tarbur Formation of Iran (= litostrati- graphic equivalent of the Simsima Fm. of Qatar), the genus Dictyoconella and the taxonomic status of its two species are herein revised.

\section{MATERIAL STUDIED}

The material studied comes from the Late Cretaceous Tarbur Formation, a predominantly carbonate lithostratigraphic unit that contains rich microfauna and microflora associated with rudists cropping out in the SW Zagros Basin (James and Wynd, 1965). The shallow water carbonates have been studied in random thin sections from two localities named Naghan and Mandegan section. The former is located in the folded Zagros belt approximately $50 \mathrm{~km}$ south west of Naghan town near the Gandomkar village ( $31^{\circ} 47^{\prime} 52^{\prime \prime} \mathrm{N}$ and $\left.50^{\circ} 32^{\prime} 53^{\prime \prime} \mathrm{E}\right)$. The Mandegan section is situated in the High Zagros Belt, north of Mount Dena, about $65 \mathrm{~km}$ south of the town of Semirom $\left(31^{\circ}, 25^{\prime}, 8.13^{\prime \prime} \mathrm{N}\right.$ and $\left.51^{\circ}, 24^{\prime}, 34.58^{\prime \prime} \mathrm{E}\right)$. For further details on the two sections see Schlagintweit et al. (2016). Dicytoconella complanata Henson and Gusicella minima (Henson) gen. et comb. nov. occur in platform carbonates of the Tarbur Formation that evolves as a shallowingupward sequence on top of the pelagic/hemipelagic Gurpi Formation. The wacke-/pack- and floatstones are rich in 


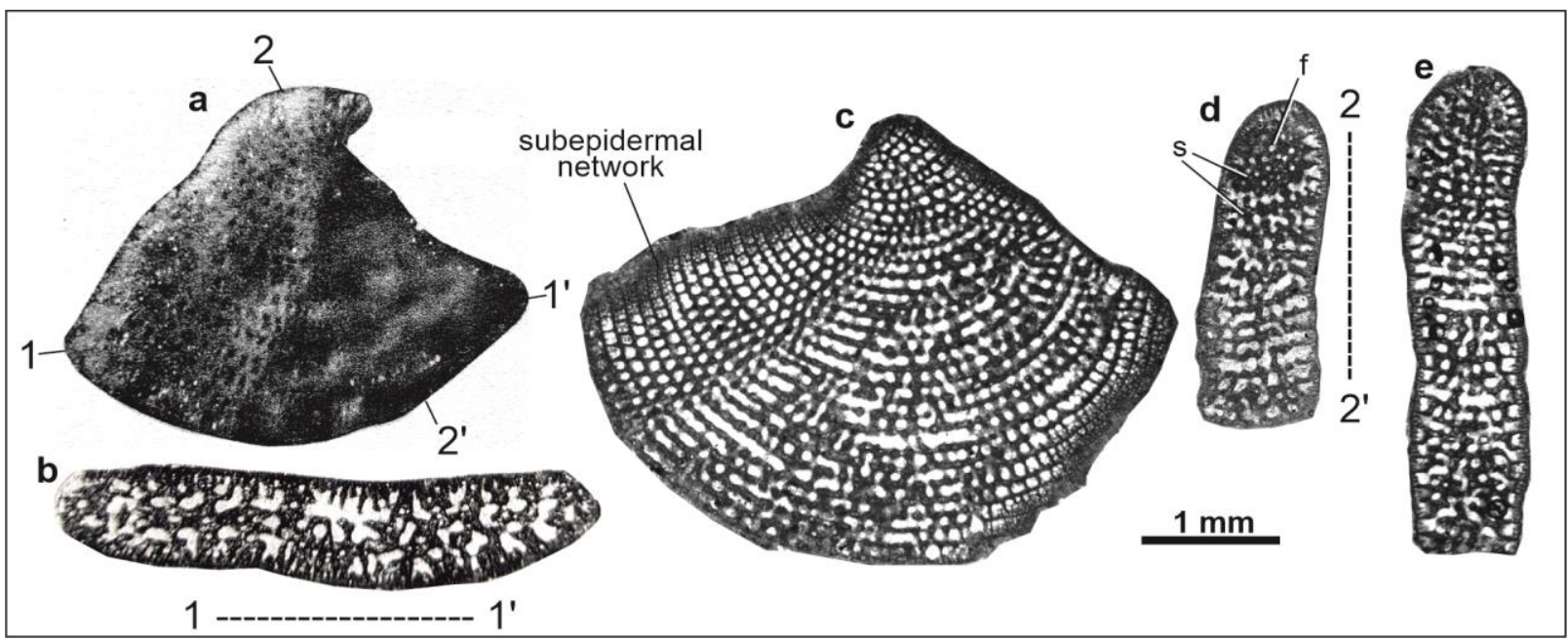

Fig. 3 Dictyoconella complanata Henson from the Maastrichtian of Qatar (a-b) and Iran (c-e). a, isolated specimen, holotype (from Henson, 1948, pl. 6, fig. 2). Section planes 1----1' and 2----2' refer to $\mathbf{b}$ and $\mathbf{d}$ respectively. b, transverse section parallel to the median plane (from Henson, 1948, pl. 6, fig. 3, parataype). c, slightly oblique median section. Note the inclination of the chambers towards the apex. Thin section $2 \mathrm{Ng} 83$. d-e, slightly oblique subaxial sections, perpendicular to the median plane ( $\mathrm{s}=$ septum, $\mathrm{f}=$ foramen). Thin sections $2 \mathrm{Ng} 81,2 \mathrm{Ng} 80-5$.

Larger Benthic Foraminifera associated with dasycladalean algae (Fig. 2). Gusicella minima occurs more common in the lower part of the Tarbur Fm. associated with Omphalocyclus and Loftusia (Wynd, 1965: Omphalocycluclus-Loftusia assemblage zone), and other taxa such as Gyroconulina columelliforma Schroeder \& Darmoian (Fig. 2c-d). D. complanata is restricted to the upper part of the Tarbur Formation in a more inner platform setting (compared to the occurrence of G. minima). Here it is associated with taxa such as Loftusia div. sp., Dicyclina schlumbergeri Munier-Chalmas, Tarburina zagrosiana Schlagintweit \& Rashidi and Pseudonummoloculina kalantarii Schlagintweit \& Rashidi (Fig. 2a-b).

\section{SYSTEMATICS}

Phylum Foraminifera d'Orbigny, 1826

Class Globothalamea Pawlowski et al., 2013

Order Loftusiida Kaminski and Mikhalevich in Kaminski, 2004

Suborder Loftusiina Kaminski and Mikhalevich in Kaminski, 2004

Superfamily Orbitolinoidea Martin, 1890

Family Orbitolinidae Martin, 1890

Subfamily Dictyoconinae Moullade, 1965

Genus Dictyoconella Henson, 1948 emended herein

Type-species: Dictyoconella complanata Henson, 1948. Holotype P.35832 in Henson (1948), in repository at the Natural History Museum London.

Diagnosis: Large-sized, laterally compressed test, flabelliform. The test displays a distinct asymmetry, with one side (with the eccentric embryo) that is wider (with respect to the central axis) and presents a concave outer periphery in equatorial section. Test base distinctly convex. Megalospheric embryo simple, biloculine with ellipsoidal protoconch and hemispherical to sickle-shaped deuteroconch, eccentric position with twisted apex. Microspheric embryo not discernible within a close-coiled whorl. Adult chambers arched and rectilinear. Exoskeleton with several orders of horizontal and vertical partitions forming a delicate subepidermal network. The marginal zone is separated from the central zone by a marginal trough. Central zone with pillars alternating between subsequent chambers. Foramina multiple in the central zone and with straight arrangement between chambers; marginal foramina are present. Wall finely agglutinated, thin, consisting of an epiderm and a delicate sub-epidermal cellular layer.

Comparisons: Morphologically, Dictyoconella is unique among all other Orbitolinidae due to its strongly compressed (flattened) test. This makes a detailed comparison to the other Upper Cretaceous genera of the Orbitolinidae superfluous. Douglass (1960, p. 256) stated that "it is likely" that Dictyoconella "is merely a variant of the genus Iraqia". This assumption must be rejected because of the difference in the central zone: reticulate in Iraqia (e.g. Moullade, 1965) and pillaroid in Dictyoconella. It is worth noting at this point that the incorrect view of Douglass was also approved by BouDagher-Fadel and Price (2009, p. 7) who included Dictyoconella in a group of "Orbitolinids with radial partitions that became zigzagged, thickening and fusing centrally. Last but not least, neither Dictyononella complanata nor "D." minima were treated in the revision of the Orbitolinidae by CruzAbad (2018) although the genus was considered valid by Loeblich and Tappan (1987). Accessible from the original samples of Qatar deposited at the Natural History Museum in London (see pictures at nhm.ac.uk), the specimens were labeled Dictyoconella (Dictyoconus) complanata by Henson. In fact, Dictyconella is best described as a distinctly compressed (flattened) Dictyoconus Blanckenhorn. Two specimens of Dictyoconella complanata were interpreted as microspheric specimens of 


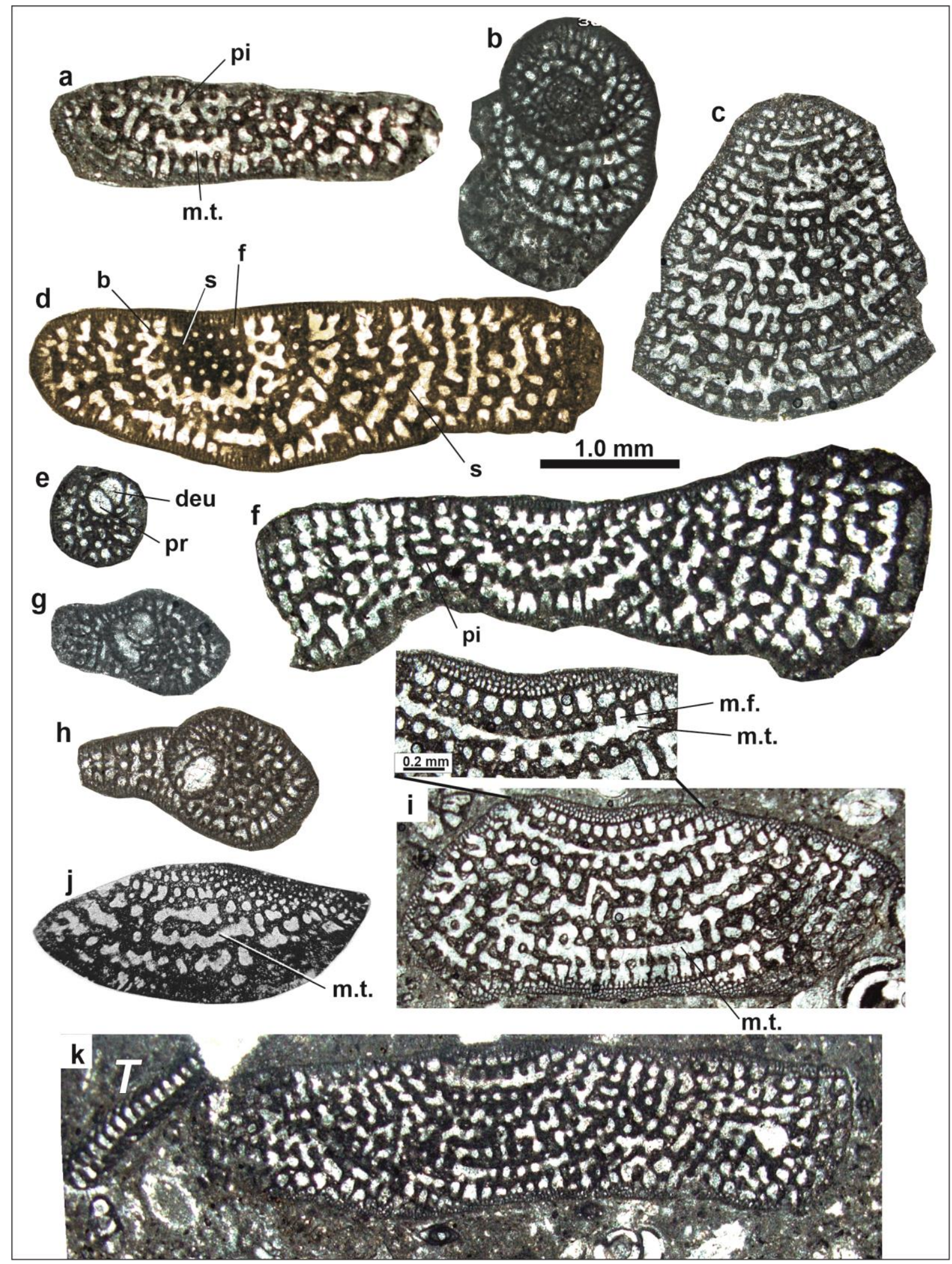

Fig. 4 Dictyoconella complanata Henson from the Maastrichtian of the Tarbur Formation of Iran (Naghan section, a-i, k) and the Simsima Formation of Qatar (j). a, d, oblique sections perpendicular to plane of compression. Note the inclination of the apical-juvenile part expressed by the parallel-sectioning of septum (s) and foramina (f) in $\mathbf{d}$. bo, oblique section passing through the initial part of a microspheric specimen. $\mathbf{c}, \mathbf{f}, \mathbf{i}-\mathbf{k}$, oblique sections in the plane of compression (j, paratype from Henson, 1948, pl. 10, fig. 14). Detail from i shows the fine subepidermal cellular network, marginal foramina and undivided marginal trough. e, g-h, oblique sections passing through the initial part of megalospheric specimens. Thin sections: $2 \mathrm{Ng} 81-$ 2 (a, d), $\mathrm{Ng} 76$ (b), 2Ng 81-3 (c), Ng 85 (e), 2Ng 87-2 (f, i), 2Ng 80-1 (g), 2Ng 85-4 (h), 2Ng 81-1 (k). Abbreviations: b = beam, deu $=$ deuteroconch, $\mathrm{f}=$ foramen $\mathrm{m} . \mathrm{f} .=$ marginal foramen, $\mathrm{m} . \mathrm{t} .=$ marginal trough, $\mathrm{pi}=$ pillar, $\mathrm{pr}=$ proloculus, $T=$ Tarburina zagrosiana Schlagintweit et al. (in k). 


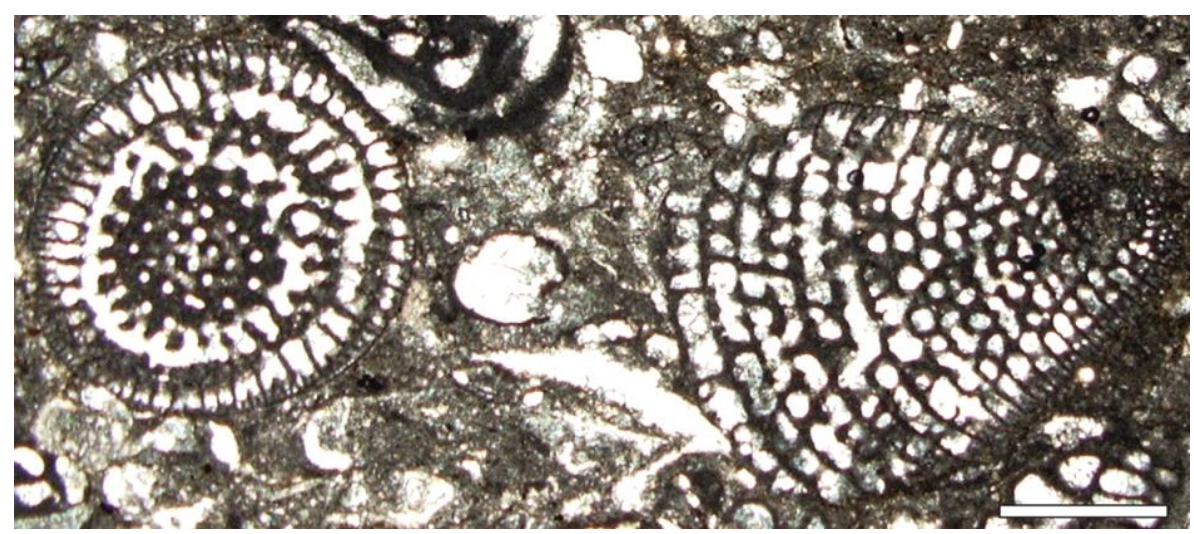

Fig. 5 Dictyoconus bakhtiari Schlagintweit et al. from the late Maastrichtian of the Tarbur Formation, SW Iran (Naghan section). Scale bar $=0.5 \mathrm{~mm}$.

\begin{tabular}{|c|c|c|c|}
\hline Genus & $\begin{array}{l}\text { Gusicella } \\
\text { nov. gen. }\end{array}$ & $\begin{array}{c}\text { Carinoconus } \\
\text { Cherchi \& Schroeder }\end{array}$ & $\begin{array}{l}\text { Dictyoconus } \\
\text { Blanckenhorn } \\
\end{array}$ \\
\hline Initial part & $\begin{array}{l}\text { embryo at the beginning of } \\
\text { a loose coil, compressed } \\
\text { with acute margin pointing } \\
\text { toward the cone base }\end{array}$ & $\begin{array}{l}\text { embryo at the beginning of } \\
\text { a closed coil, compressed } \\
\text { with acute margin pointing } \\
\text { toward the apex }\end{array}$ & $\begin{array}{l}\text { embryo at the beginning of } \\
\text { a closed coil, uncompressed } \\
\text { with rounded margin }\end{array}$ \\
\hline $\begin{array}{c}\text { transverse } \\
\text { sections }\end{array}$ & \multicolumn{2}{|c|}{ circular, compressed in the early stage } & circular \\
\hline $\begin{array}{c}\text { Exoskeleton } \\
\text { primary vertical } \\
\text { partitions } \\
\end{array}$ & $\begin{array}{l}\text { complex: several orders } \\
\text { of rafters and beams } \\
\text { aligned between } \\
\text { successive chambers }\end{array}$ & $\begin{array}{l}\text { simple: no rafters, } \\
\text { beams and one } \\
\text { intercalary beam } \\
\text { alternating between }\end{array}$ & $\begin{array}{l}\text { complex: one to several } \\
\text { orders of rafters, and } \\
\text { several orders of beams } \\
\text { successive chambers }\end{array}$ \\
\hline \multirow[t]{2}{*}{ Endoskeleton } & \multicolumn{3}{|c|}{ pillars, alternating between successive chambers; } \\
\hline & \multicolumn{2}{|c|}{ there may be secondary calcitic fillings } & no secondary calcitic fillings \\
\hline $\begin{array}{l}\text { Marginal } \\
\text { foramina }\end{array}$ & yes & no & yes \\
\hline $\begin{array}{l}\text { suprageneric } \\
\text { position }\end{array}$ & Dictyorbitolininae & \multicolumn{2}{|c|}{ Dictyoconinae } \\
\hline
\end{tabular}

Fig. 6 Comparison of Gusicella gen. nov., Carinoconus Cherchi \& Schroeder, and Dictyoconus Blanckenhorn.

Dictyoconus bakhtiari by Schlagintweit et al. (2016) but this taxonomic interpretation is revised herein. Dictyoconus has a medium-high conical test with circular transverse section (Fig. 5). Notably, this feature alone is generally given generic importance. Examples are the Liassic forms Lituosepta Cati, 1959 (uncompressed) and Planisepta Septfontaine in Kaminski, 2000 (compressed), the Lowermost Cretaceous Scythiolina Neagu, 2000 (compressed) and Histerolina Neagu, 2000 (uncompressed), or the Paleogene Rhapydionina Stache, 1913 (uncompressed) and Fanrhapydionina Fleury, 2014 (compressed).

Dictyoconella complanata Henson, 1948

Figs. 2a-b pars, 3-4

1948 Dictyoconella complanata n. gen., n. sp. - Henson, p. 25 , plate 6 , figs. $2-3,16$, pl. 10, fig. 14 .
1986 Dictyoconella complanata Henson - Köylüoğlu, pl. 86, fig. 1 pars.

1998 Dictyoconella complanata Henson - Whittaker et al., pl. 47, figs. 4-6.

2016 Dictyoconus bakhtiari Schlagintweit et al. - Schlagintweit et al., fig. 8g, fig. $10 \mathrm{f}$.

2020 Dictyoconella complanata Henson -Schlagintweit, p. 75 , fig. $4 d-f$.

Description: See the genus description.

\section{Dimensions:}

Test diameter: up to $4.8 \mathrm{~mm}$ (3.3 mm, holotype specimen of Henson, 1948)

Test height: $3.6 \mathrm{~mm}$ (2.9 mm, holotype specimen of Henson, 1948)

Thickness: mostly between 0.8 and $0.9 \mathrm{~mm}(\sim 0.8 \mathrm{~mm}$, Henson, 1948) 


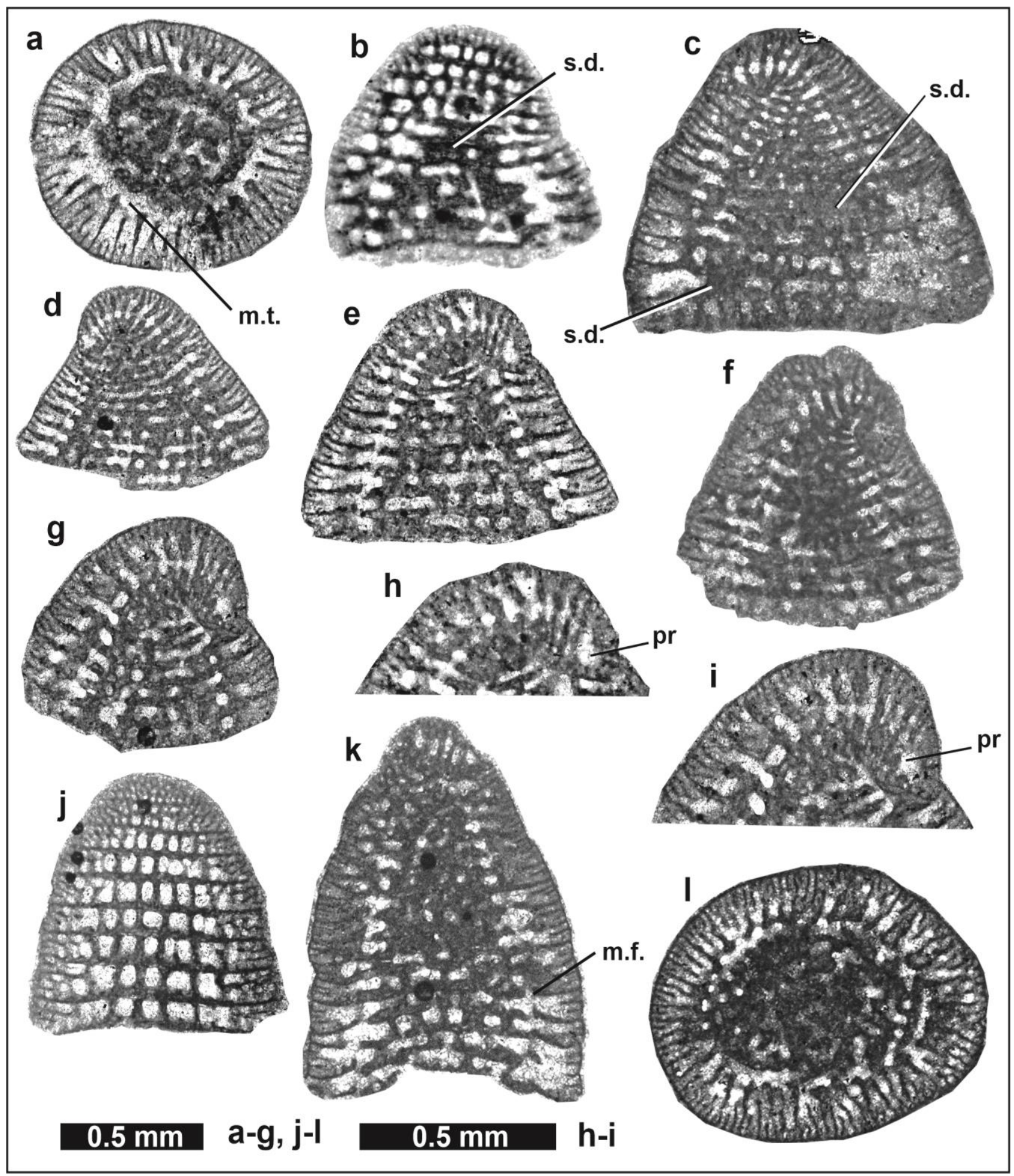

Fig. 7 Gusicella minima (Henson) gen. et comb. nov. from the late Maastrichtian of the Tarbur Formation, SW Iran (Mandegan section: b, l; Naghan section: a, c-k). a Oblique transverse section. b Oblique section cutting the marginal (upper part) and central zones (lower part) displaying irregularly distributed fused pillars/secondary deposits. c, k Subaxial sections. d-g, Axial sections showing initial spire. $\mathbf{h}-\mathbf{i}$ Details (from $\mathbf{e}$ and $\mathbf{g}$ ) of the initial spire. $\mathbf{j}$ Tangential section. Slightly oblique transverse sections showing subdivision of the marginal zone and circle of marginal apertures (left and above). Abbreviations: m.f. = marginal foramen, m.t. $=$ marginal trough, $\mathrm{pr}=$ protoconch, $\mathrm{s.d}$. = secondary deposits/fused pillars. Thin sections: $2 \mathrm{Ng} 17$ (a, k), Rt 100 (b), $\mathrm{Ng} \mathrm{180-1} \mathrm{(c),} \mathrm{2Ng} \mathrm{179-1}$ (d), $2 \mathrm{Ng} 168(\mathbf{e}, \mathbf{h}), 2 \mathrm{Ng} 175$ (f), $2 \mathrm{Ng} 174(\mathbf{g}, \mathbf{i}), 2 \mathrm{Ng} 177$ (j), Rt 113 (l). 


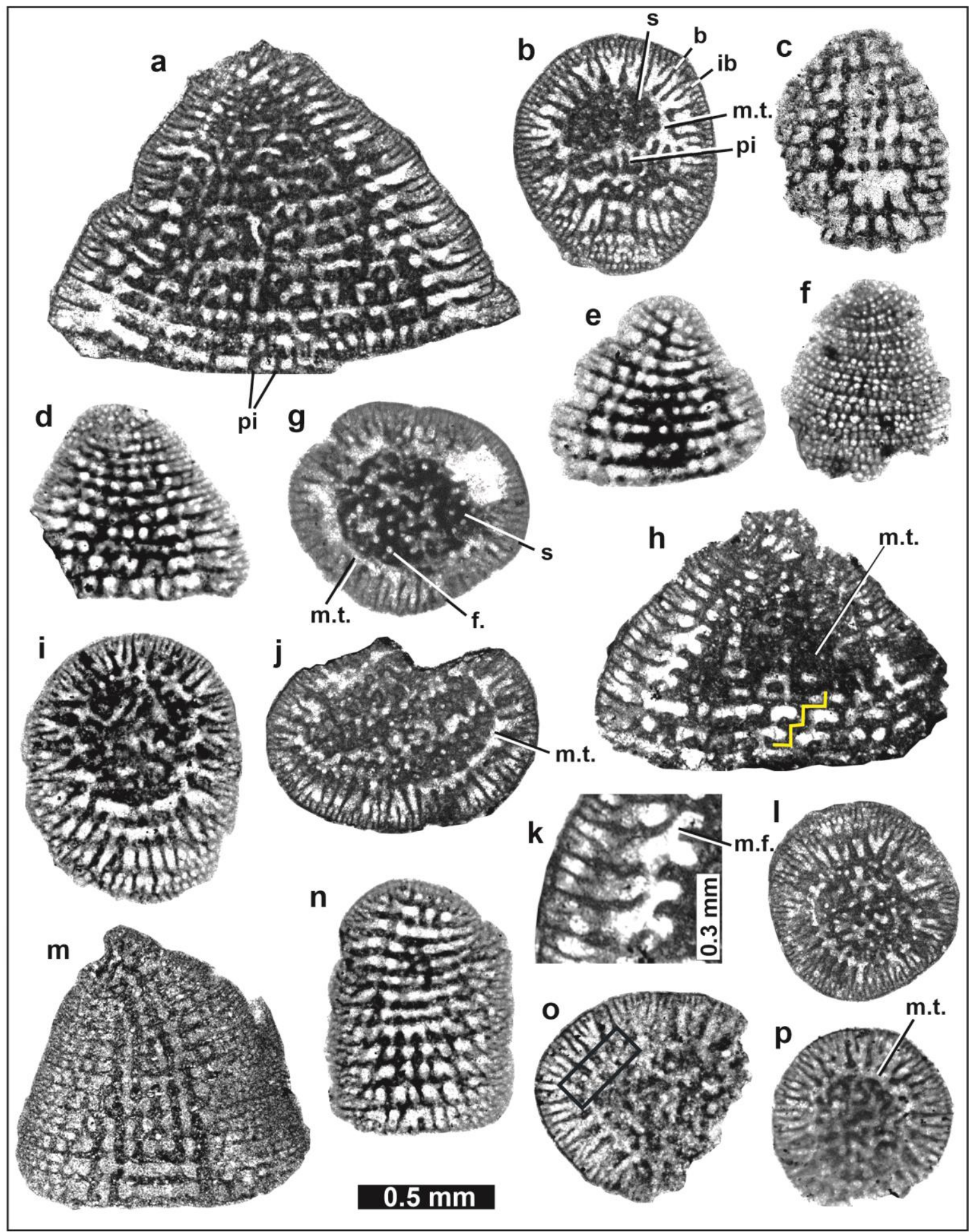

Fig. 8 Gusicella minima (Henson) gen. et comb. nov. from the late Maastrichtian of the Tarbur Formation, SW Iran (Naghan section: a-b, j, l; Mandegan section: $\mathbf{c}-\mathbf{i}, \mathbf{k}, \mathbf{m}-\mathbf{p})$. a Subaxial section. b, i, l Oblique sections. c-e, m Deep tangential sections displaying primary septules (beams) continuous (aligned) from one chamber to the next. f Shallow tangential section displaying subepidermal network of beams and rafters. $\mathbf{g}, \mathbf{j}, \mathbf{l}, \mathbf{0}-\mathbf{p}$ Different transverse sections, some slightly oblique. Note five marginal foramina arranged in a radial circle (inside yellow marked rectangle in o). Note oval test outline in $\mathbf{j}$. Subaxial section. Note alternation of pillars by stairway-like arrangement of foramina (yellow line) and opaque fused pillars/secondary deposits in the central zone. $\mathbf{k}$ Detail from $\mathbf{h}$ showing marginal foramina arranged in vertical lines between successive chambers. $\mathbf{n}$ Tangential-oblique section. Abbreviations: $b=$ beam, $i b=$ intercalary beam, $f=$ foramen, m.f. = marginal foramen, m.t. = marginal through, pi = pillar, s = septum. Thin sections: $\mathrm{Ng} 196(\mathbf{a}), \mathrm{Ng} 192$ (b), Rt 108-3 (c-e, g, n), Rt 104 (f), Rt 96 (h, k), Rt 108-6 (i), Ng 187 (j), Ng 186 (l), Rt 107 (m), Rt 102-2 (o), Rt 104 (p). 
Number of chambers last mm axial length: 7-9 (about 7, Henson, 1948)

Remarks: The dimorphism of D. complanata is well constrained by the biloculine embryo in the A-form and an indiscernible embryo within a close-coiled whorl including more chambers in the B-form (one section only, see Fig. 4b). The differences in the external test morphology between the two generations are unknown. In the family Orbitolinidae, B-specimens are generally larger and more flattened (e.g. Hofker, 1966). In the Iranian Tarbur Formation, D. complanata is comparably rare and only a couple of sections are available. Due to the revision presented herein, Dictyoconella becomes a monospecific genus and an assumed Maastrichtian newcomer that became extinct shortly afterwards at the K-Pg boundary. Besides the Tarbur Formation of Iran, D. complanata has been reported so far from the Maastrichtian Garzan Formation of southeastern Turkey (Köylüoğlu, 1986) revealing some kind of bioprovincialism, which requires subsequent study (Schlagintweit, 2020a).

Subfamily Dictyorbitolininae Schroeder, 1990 (in Schroeder et al., 1990)

Remarks: Subfamily Dictyorbitolininae includes the following genera: Dictyorbitolina Cherchi \& Schroeder, 1976, Praedictyorbitolina Schroeder in Schroeder et al., 1990, Paracoskinolina Moullade, 1965 (see Schroeder in Schroeder et al., 1990) of the Lower Cretaceous, Gusicella gen. nov. of the Upper Cretaceous, and Schroedericonus Schlagintweit, 2020b of the Paleogene.

Genus Gusicella n. gen.

Type species: Dictyoconella minima Henson, 1948. Holotype P.35838 in Henson (1948), stored at the Natural History Museum London (see also https://data.nhm.ac.uk).

Derivation of the name: The name is dedicated to Ivan Gusič for his numerous contributions to Mesozoic benthic foraminifera and dasycladalean algae.

Diagnosis: Finely agglutinated shell of medium conical morphology; wall thin, without any texture. Early stage with small embryo and an eccentric spire consisting of a few compressed chambers ( $\sim$ half a whorl) displaying an angular margin in vertical section. Transverse section of the cone can be slightly compressed. Adult conical part with numerous rectilinear chambers subdivided into marginal and central zones separated by an undivided marginal trough. Marginal zone with several orders of beams and rafters forming a polygonal network. Main vertical partitions (beams) continuous between chambers. Central zone with pillars alternating between successive chambers; secondary deposits may be present. Marginal foramina are inclined at about 45 degrees with respect to the cone axis and form a circular row at the outer margin of the marginal trough. Multiple foramina situated in the central test part. Microspheric forms presumably broader and with convex cone base.
Comparisons: Due to the vertically alignment of the main partitions, Gusicella belongs to the Dictyorbitolininae as defined by Schroeder in Schroeder et al. (1990). Gusicella is so far the only genus of the Dictyorbitolininae reported from the Late Cretaceous Global Community Maturation Cycle of larger benthic foraminifera (e.g., Hottinger, 1997, Consorti, 2017). Dictyoconella Henson instead with its alternating vertical skeletal elements belongs to the Dictyoconinae Moullade (see discussion in Schlagintweit et al., 2016). The discreteness of Gusicella gen. nov. is given by the combined features of the initial part, and structural (exo- and endoskeleton) and foraminal features. Dictyorbitolina Cherchi and Schroeder has an apical embryo consisting of a simple protoconch and septulate deuteroconch, and alternating pillars in the central zone. It is worth noting that Dictyorbitolina was previously placed within the subfamily Orbitolininae (Cherchi and Schroeder, 1976; Loeblich and Tappan, 1987), then transferred to the Dictyorbitolininae by Schroeder in Schroeder et al. (1990). Praedictyorbitolina Schroeder et al., 1990 has a simple embryo in eccentric position and alternating pillars in the central zone. In Paracoskinolina Moullade, 1965, the main partitions and pillars are aligned between the consecutive chambers.

Henson (1948, p. 24-25) noted the presence of a "zone with undivided chamber space" (or marginal ridge) between the marginal (with exoskeleton) and central zones (with endoskeleton; see also Hottinger, 2006, p. 22) as also described from Dictyoconus Blanckenhorn by Davies (1930: marginal trough; see Figs. 7a, 9d). Henson (1948, p. 26) also noted that in D. minima "the interseptal structures are sporadic and poorly defined in the central shield" (= central zone). In this context, Henson (ibidem) was obviously referring to the presence of secondarily infilled shell material as for instance reported from the Pfenderinidae Smout and Sugden or the orbitolinid Carinoconus Cherchi \& Schroeder (Loeblich and Tappan, 1987). The characteristics compared to those of the dictyoconid genera Carinoconus Cherchi \& Schroeder and Dictyoconus Blanckenhorn are compiled in figure 6.

Remarks: The new compilation shows that the postCenomanian Upper Cretaceous Orbitolinidae consists of nine genera which in alphabetical order are: Abrardia Neumann \& Damotte, Calveziconus Caus \& Cornella, Dictyoconella Henson, Dictyoconus Blanckenhorn, Falsurgonina Arnaud-Vanneau, Gusicella Schlagintweit \& Rashidi, Orbitolinopsis Henson, Paleodictyoconus Moullade, and Pseudorbitolina Douvillé.

Gusicella minima (Henson, 1948) comb. nov.

Figs. 2c-d, 7-9

*1948 Dictyoconella minima n. sp. - Henson, p. 25, pl. 11, fig. 3, 8-10.

1998 Dictyoconella minima Henson - Whittaker et al., pl. 4 , fig. 3 , pl. 5, figs. $1-2$, pl. 48 , figs. 1-4.

2008 Dictyoconella minima Henson - Schlagintweit et al., p.34, fig. 3a-b pars, 5-6. 


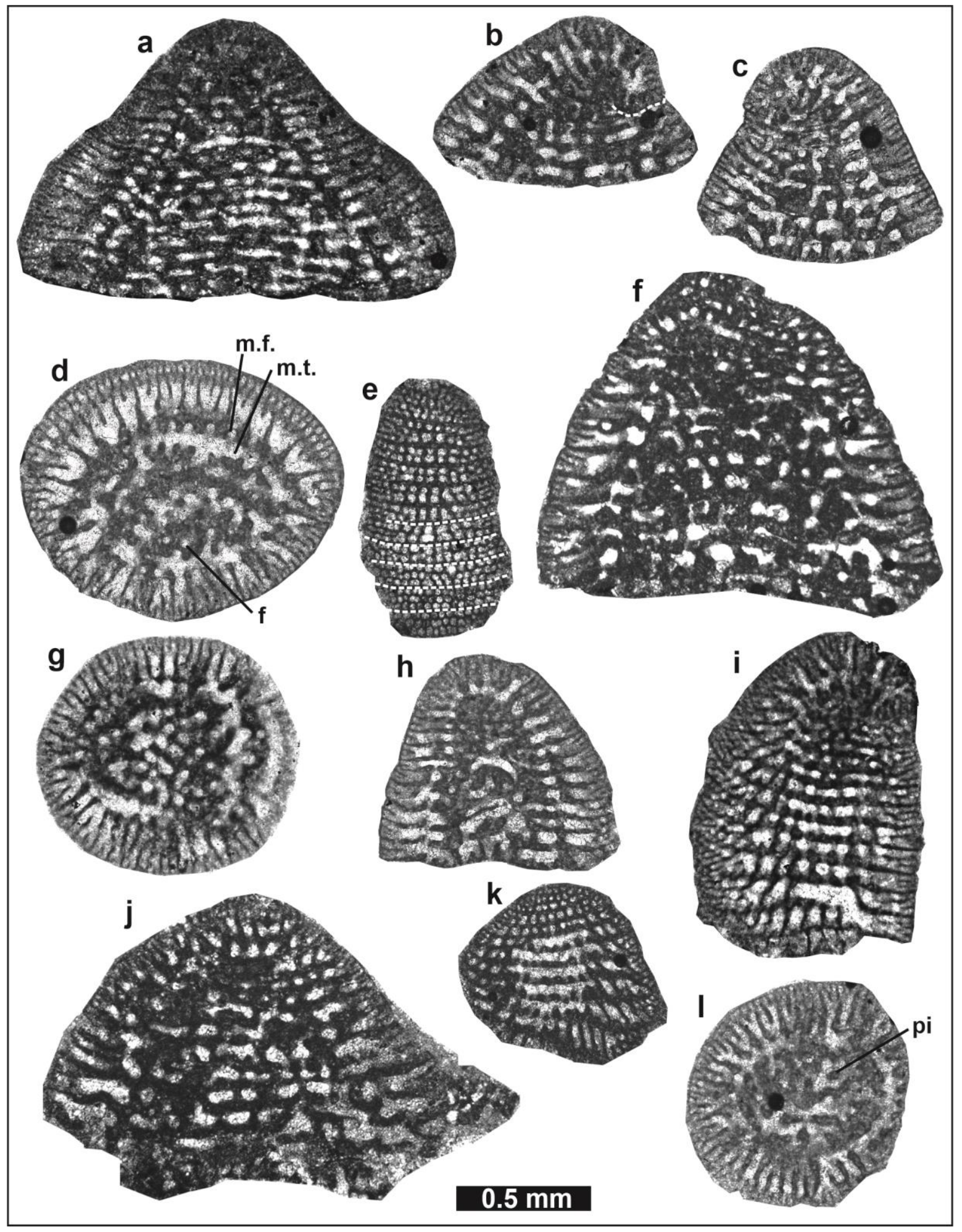

Fig. 9 Gusicella minima (Henson) gen. et comb. nov. from the late Maastrichtian of the Tarbur Formation, SW Iran (Naghan section: $\mathbf{c}-\mathbf{f}, \mathbf{h}-\mathbf{k}$ ); Mandegan section: $\mathbf{a}-\mathbf{b}, \mathbf{g}, \mathbf{l})$. a subaxial section of an assumed microspheric specimen. $\mathbf{b}-\mathbf{c}$ axial sections showing initial spire with acute margin beneath the apex. $\mathbf{d}$ oblique section showing the marginal trough between the marginal and central zones as well as a circular row of marginal apertures between. e tangential section showing subepidermal network; septa in the lower part marked by white dash lines. f subaxial section of a possibly microspheric specimen. $\mathbf{g}$ transverse section. $\mathbf{h}$ subaxial section. $\mathbf{i}$ tangential section showing aligned main beams. $\mathbf{j}$ subaxial section of a possibly microspheric specimen. $\mathbf{k}$ tangential section. $\mathbf{l}$ slightly oblique transverse section showing several orders of vertical partitions (beams, intercalary beams), marginal trough, and pillared central zone. Abbreviations: m.f. $=$ marginal foramen, m.t. = marginal through, pi = pillar. Thin sections: Rt 105 (a), 2Ng 17 (c), Rt 96 (b), 2Ng 167 (d), $2 \mathrm{Ng} 174$ (e), 2Ng 118-1 (f), Rt 108-2b (g), 2Ng 169 (h), 2Ng 191 (i), 2Ng 176 (j), 2Ng 146 (k), Rt 111-1 (l). 
Description: Test medium conical (apical angle from 50 to 90 degrees); both sides and cone base slightly convex. Assumed microspheric specimens broader and larger (Fig. 8a, 9a, 9f, 9j). Transverse sections circular (Fig. 8p) or ovoidal-compressed (Fig. 71, 8j). The initial part is characterized by a small spire of few chambers arranged in half a whorl that is closely attaching (almost parallel) to the side test wall (Fig. 7d, g, i, 9b). The acute apex is tilted, marking the early development in a downwards turning to the cone base (e.g. Fig. $7 \mathrm{~g}$ ). The megalospheric embryo appears as a single subspherical chamber (protoconch) showing short septules at its upper part facing the cone base (Fig. 7g-i). The chambers are subdivided into marginal and central zones. The exoskeleton consists of horizontal (rafters) and radial vertical partitions (beams) subdividing the chamber margins. There are one to three rafters in the marginal zone (e.g. Fig. 7e). In case of two rafters, the upper one (in direction to the apex) is twice as long as the lower one. In case of three rafters, the middle one is roughly twice as long as the others. There are two to three intercalary beams between the longer main partitions (beams) (Fig. 8p, 9d). The latter are continuous from one chamber to the next (Fig. 8c, 8m, 9i). They extend to the undivided marginal through marking the boundary to the central zone (Fig. 7a, 9d). Here, the septa slightly bend upwards in direction to the apex forming a "buttress on marginal ridge" sensu Davies (1930) as seen in axial sections (Fig. 8k). Shallow-tangential sections display a pattern of subrounded alveolar compartments (subepidermal network) (Fig. 7j, 8f, 9e). At their distal ends the primary beams are moderately thickening. The marginal chamberlets are tapering distally terminating inwards with a marginal foramen, oriented at about 45 degrees to the main axis. In transverse sections they form a circular ring (Fig. 71, 8k, 8o). Foramina can form a continuous line running parallel to the outer test surface as seen in axial sections (Fig. 7e, 8a). Certain portions of the central zone are filled with opaque micritic masses (fused pillars and/or secondary deposits) that obliterate the original structure (Fig. 7b-c, 8h). The pillars of the central zone are comparably narrowly spaced and alternate between consecutive chambers (Fig. 7c-d, 8a, h, 9f). In the central part, the foramina present a cribrate distribution and are vertically arranged.

Dimensions (in mm; data from Henson, 1948, between brackets):

Test diameter (D): 0.7-1.9 mm $(0.7-1.8 \mathrm{~mm})$. Note: specimens with a test diameter $>1.5 \mathrm{~mm}$ appear to be miscrospheric specimens.

Test height $(\mathrm{H}): 0.8-1.4(1.0-1.5 \mathrm{~mm})$

D/H: 0.8-1.35

Numbers of chambers per $1 \mathrm{~mm}$ of the axial length: $12-$ 16 , mostly 15-16 (15)

Remarks on stratigraphy: Henson (1948) reported $D$. minima "most probably" from the late Cenomanian or Turonian of Qatar (Dukhan no. 2 and 3 wells; Wasia Group, see figs. 1-2 in Sugden and Standring, 1975). In addition, Henson (op. cit, p. 26) noted "a single speci- men, possibly of this species" from the Maastrichtian of Iraq. For the Dukhan oil field of Qatar, Hewaidy and AlHitmi (1994) established a Late Cenomanian "Dictyoconella minima total range Zone". The "zonal taxon" however, has not been illustrated and therefore, cannot be commented. Within the framework of our observations in the Cenomanian Sarvak Formation of Iraq (e.g. YazdiMoghadam and Schlagintweit, 2020), no specimens of $G$. minima have been observed. There are specimens of an orbitolinid displaying a pillared central zone and a complex exoskeleton that needs further taxonomic study and evaluation, and it is different from G. minima. So far, only the occurrence in the Maastrichtian is well constrained and older occurrences require further study.

\section{CONCLUSIONS}

The generic individuality of Dictyoconella Henson is reinstated herein. The taxonomic revision however, leads to the genus monotypy, including only the type-species D. complanata. The taxon described as Dictyoconella minima Henson is considered a separate new genus: Gusicella, which is also a monospecific taxon. Gusicella is the first and thereby only representative of the subfamily Dictyorbitolininae in the Upper Cretaceous. Both Dictyoconella and Gusicella are restricted to the Upper Cretaceous and became extinct at the K-Pg boundary massextinction event.

\section{ACKNOWLEDGEMENTS}

Thanks to Cemile Solak (Mersin) for providing Turkish literature. The two reviewers Lorenzo Consorti (Rome) and François Le Coze (Saint-Étienne) are thanked for provising helpful comments. Marius (Dan) Georgescu (Calgary) assisted with the English.

\section{REFERENCES}

Cati, F., 1959. Nuovo Lituolide nei calcari grigi Liassici del Vincento. Giornale di Geologia, 27: 1-10.

Cherchi, A., Schroeder, R., 1976. Dictyorbitolina ichnusae n. gen., n. sp. (Foram.) del Barremiano della Sardegna nord-occidentale. Bolletino della Società Paleontologica Italiana, 14: 47-54.

Consorti, L., 2017. Selected larger benthic foraminifera (LBF) from the Middle and Late Cretaceous Global Community Maturation Cycles in two adjoining palaeobioprovinces: Pyrenees and Tethys. $\mathrm{PhD}$ Thesis University of Bracelona: 1-125. Online: www.tesisenred.net/handle/10803/403772\#page =1

Cruz-Abad, E., 2018. Textura y Arquitectura de los Orbitolinoideos (Superfamilia Orbitolinoidea): Revisión y Caracterización. PhD Thesis University of Barcelona, 154 p. Online: https://www.tesisenred.net/handle/10803/665998\#pag $\mathrm{e}=1$ 
Davies, L.M., 1930. The genus Dictyoconus and its allies: A review of the group, together with a description of three new species from the Lower Eocene beds of northern Baluchistan. Transactions of the Royal Society of Edinburgh 56 part II (no. 20): 485-505.

Douglass, R.C., 1960. Revision of the family Orbitolinidae. Micropaleontology, 6(3): 249-270.

Fleury, J.-J., 2014. Données nouvelles sur Rhapydionina Stache, 1913 et Fanrhapydionina n. gen., un groupe de Rhapydioninidae (Alveolinacea, Foraminifera) foisonnant en region périadriatique au CampanienMaastrichtien. Geodiversitas, 36 (2): 173-208.

Hewaidy, A.G.A, Al-Hitmi, H.A., 1994. CretaceousEarly Eocene biostratigraphy of the Dukhan oil field, west Qatar, Arabian Gulf. M.E.R.C. Ain Shams University, Earth Science Series, 8: 1-24.

Henson, F.R.S., 1948. Larger imperforate Foraminifera of south-western Asia. Families Lituolidae, Orbitolinidae and Meandropsinidae. London, Monograph British Museum (Natural History): 1-127.

Hofker, J. Jr., 1966. Studies on the family Orbitolinidae. Palaeontographica, Abt. A, 126: 1-34.

Hottinger, L., 1997. Shallow benthic foraminiferal assemblages as signals for depth of their deposition and their limitations. Bulletin de la Société géologique de France, 168 (4): 491-505.

Hottinger, L., 2006. Illustrated glossary of terms used in foraminiferal research. Carnets de Géologie / Notebooks on Geology - Memoir 2006/02: 1-126.

James, G.A., Wynd, J.G., 1965. Stratigraphic Nomenclature of Iranian Oil Consortium Agreement Area. AAPG Bulletin, 49 (12): 2218-2232.

Kaminski, M.K., 2000. The new and reinstated genera of agglutinated foraminifera published between 1986 and 1996. In: Hart, M.B., Kaminski, M.A., Smart, C.W. (eds.) Proceedings of the Fifth International Workshop on Agglutinated Foraminifera. Grzybowski Foundation Special Publication, 7: 185-219.

Kaminski, M.A., 2004. The year 2000 classification of the agglutinated foraminifera. In: Bubík, M., Kaminski, M.A. (eds), Proc. $6^{\text {th }}$ Int. Workshop agglutinated foraminifera. Grzybowski Foundation Special Publication, 8: 237-255.

Köylüoğlu, M., 1986. Güneydoğu Anadolu otokton birimlerin kronostratigrafisi, mikrofasiyes ve mikrofosilleri, T.P.A.O. Araştırma Merkezi, Eğitim Yayınları, 9: 1-53.

Loeblich, A.R., Jr., Tappan, H., 1987. Foraminiferal genera and their classification, Van Nostrand Reinhold, New York, 2 vol., 970 p., 847 pls.

Martin, K., 1890. Untersuchungen über den Bau von Orbitolina (Patellina auct.) von Borneo. Sammlungen des Geologischen Reichs-Museums in Leiden, ser. 1, 4: 209-231.
Moullade, M., 1965. Contribution au problème de la classification des Orbitolinidae (Foraminiferida, Lituolacea). Comptes rendus de l'Académie des Sciences, 260: 4031-4034.

Neagu, T., 2000. Lower Cretaceous calcareous agglutinated foraminifera from southern Dobrogea, Romania. Part II. Early Cretaceous Cuneolinidae. In: Hart, M.B., Kaminski, M.A., Smart, C.W. (eds.) Proceedings of the Fifth International Workshop on Agglutinated Foraminifera. Grzybowski Foundation Special Publication, 7: 363-386.

Orbigny, A., d', 1826. Tableau méthodique de la classe des Céphalopodes. Annales des Sciences Naturelles, 7: 245-314.

Pawlowski J., Holzmann, M., Tyszka, J., 2013. New supraordinal classification of Foraminifera: Molecules meet morphology. Marine Micropaleontology, 100: 110.

Schlagintweit, F., 2020a. Maastrichtian larger benthic foraminifera from the Arabian Plate sensu lato: new data from Somalia, Turkey and Iran. Acta Palaeontologica Romaniae, 16 (2): 69-83.

Schlagintweit, F., 2020b. Schroedericonus n. gen. (typespecies Dictyoconus turriculus Hottinger and Drobne, 1980), Paleocene larger benthic foraminifera (Orbitolinidae). Revue de Micropaléontologie, 68: article 100441.

Schlagintweit, F., Rashidi, K., Babadipour, M., 2016. Orbitolinid foraminifera from the Late Maastrichtian of the Tarbur Formation (Zagros Zone, SW Iran). Acta Palaeontologica Romaniae, 12 (2): 29-46.

Schroeder R., Clavel, B., Charollais, J. 1990. Praedictyorbitolinina carthusiana n. gen., n. sp., Orbitolinidé (Foraminiferida) de la limite Hauterivien-Barrémien des Alpes occidentales. Paläontologische Zeitschrift, 64(3/4): 193-202.

Stache, G., 1913. Über Rhipidionina St. und Rhapydionina St. Jahrbuch der Geologischen Reichsanstalt, 62 (1912): 659-680.

Whittaker, J., Wynn Jones, B., Banner, F., 1998. Key Mesozoic Benthic Foraminifera of the Middle East. The Natural History Museum, London: 1-237.

Wynd, J.G., 1965. Biofacies of the Iranian Oil Consortium Agreement Area. IOOC Report, No. 1082: 189.

Yazdi-Moghadam, M., Schlagintweit, F., 2020. Persiconus sarvaki gen. et sp. nov., a new complex orbitolinid (Foraminifera) from the Cenomanian of the Sarvak Formation (SW Iran, Zagros Zone). Cretaceous Research, 109: article 104380. 